\title{
Risk evolution: how can changes in the built environment influence the potential loss of natural hazards?
}

\author{
B. Schwendtner, M. Papathoma-Köhle, and T. Glade \\ University of Vienna, Department of Geography and Regional Research, Vienna, Austria \\ Correspondence to: B. Schwendtner (schwendtnerbarbara@gmail.com)
}

Received: 19 December 2012 - Published in Nat. Hazards Earth Syst. Sci. Discuss.: Revised: 2 April 2013 - Accepted: 24 May 2013 - Published: 10 September 2013

\begin{abstract}
Alpine areas often suffer significant loss and damage due to a range of natural processes such as landslides, debris flows, snow avalanches or floods. Sealing of the soil surface, settling in endangered areas and enhanced human intervention in the natural settings, as well as socio-economic changes, increase the risk and susceptibility of built environments to natural hazards and the costs of the consequences in a spatio-temporal context. The present study examines the loss estimation of a particular debris flow event for different points in time. The event occurred in August 1987, affected the municipality Martell in South Tyrol, Italy, and resulted in a total cost of $€ 25$ million. The approach presented in this paper focuses on the changes of the land use and settlement expansion in the area since 1954 and attempts to assess the monetary impact of a similar event, which could have happened before $(1954,1985)$ or following the actual event $(1992,1999,2006)$. The method applied is based on the use of a vulnerability curve which was developed for the specific area, based on the documentation of the damage of the 1987 event. Based on this curve, a loss estimation was carried out in order to visualise the risk evolution in a period of $52 \mathrm{yr}$ (1954 to 2006). The results show a significant increase in the extent of the built environment (number, size and value of buildings) which consequently reflect an increase of the potential overall loss through the years. The method can be used in order to assess the potential loss for future scenarios based on different spatial patterns of the built environment.
\end{abstract}

\section{Introduction}

Floods, snow avalanches, debris flows, landslides and rock falls are only some of the processes that are often responsible for significant loss of life and physical damage to any kind of objects in Alpine regions. Climate change is expected to influence the frequency and magnitude of such events (IPCC, 2012). Moreover, development of the Alpine areas and significant changes to land use and land cover, as well as socio-economic changes (spatial pattern of the built environment, changes in population density, expansion of agricultural or settlement areas) over time, are expected to change the pattern of elements at risk of the Alpine communities and their damage potential (Fuchs et al., 2005; Hufschmidt et al., 2005; Keiler, 2004; Keiler et al., 2005). The influence of these changes on possible consequences of future events needs to be taken into account when planning in an Alpine environment. A comprehensive system of risk management and prevention measures is important, in order to reduce the potential losses. Considering that, the evaluation of risk evolution and the changes of the potential consequences of natural hazards referring to past events are of great significance (Keiler et al., 2006). Decision makers and other stakeholders are in need of tools and methods that will assist them in developing an overview of possible consequences and more specifically monetary losses in order to carry out cost-benefit analysis for possible structural mitigation measures.

The importance of vulnerability analysis for the design of risk reduction strategies has been emphasised in numerous studies (Papathoma-Köhle et al., 2011, 2012a, b; Fuchs et al., 2005, etc.). Vulnerability curves, wherever these are available, can be used for the estimation of the potential loss as long as the intensity, velocity or pressure, which will affect each building, is known. Vulnerability, as a term, is thoroughly discussed by scientists of various disciplines concerning its definition and application. In this study, the focus is on physical vulnerability and, for this reason, vulnerability is defined as the "degree of loss to a given element or a set of elements within the area affected by a hazard. It is 
expressed on a scale of 0 (no loss) to 1 (total loss)" (UNDRO, 1984). There is no standard methodology in assessing physical vulnerability (Papathoma-Köhle et al., 2011), however, besides vulnerability matrices and fragility curves (Eidsvig, 2009), vulnerability curves are widely used in the field of natural hazards generally and more specifically for debris flows (Akbas, 2009; Fuchs et al., 2007; Quan-Luna et al., 2011; Papathoma-Köhle et al., 2012a, b).

Vulnerability curves express the relationship between the degree of loss of a specific element at risk and the intensity of the process. In the case of debris flows, the intensity of the process is often expressed as the deposition height (Papathoma-Köhle et al., 2011; Rickenmann, 2001) but also as impact pressures or kinematic viscosity (Quan Luna et al., 2011) or pressure. The disadvantages of vulnerability curves are that they do not consider any additional characteristic of the analysed buildings, require a significant amount of data to be reliable and that they are not easily transferable to other research areas having different structural characteristics. However, vulnerability curves provide an approximation of the way elements at risk resist or fail under the impact of different forces and are translating loss in monetary terms.

The aim of the present study is to carry out a new approach of loss estimation using existing vulnerability curves to assess potential loss of hazardous events in the future considering past changes in the spatial pattern of elements at risk. The study uses a spatio-temporal approach to evaluate the degree of loss in a specific area assuming that a debris flow event, which originally occurred in August 1987, happens again at a different point in time. The research question focuses on estimating the potential consequences for the debris flow having an impact on elements at risk in the study area for selected research years (1954, 1985, 1992, 1999 and 2006).

\section{Study area and event description}

The municipality of Martell is located in the identically named tributary valley of Vinschgau in South Tyrol, Italy (Fig. 1). The altitude ranges from $950 \mathrm{~m}$ up to $3700 \mathrm{~m}$ a.s.l. to the glacier covered mountains in the southern part of the $27 \mathrm{~km}$ long valley (Martell, 2013). Major parts of the valley are of high-Alpine character, the tree-line ranges between 2100 to $2300 \mathrm{~m}$ a.s.l., whereas the valley bottom is intensively used for agriculture. The settlement areas, namely the main village Meiern and several smaller but more densely settled parts (Gand, Ennewasser and Burgaun), are located in the north. In general, the climate in South Tyrol is rather dry and strongly influenced by the surrounding mountain ranges. Locally, heavy precipitation is a common triggering factor for debris flows, landslides and flash floods (Bell et al., 2010). The record of precipitation data shows a significantly high rainfall sum for August 1987, the period when the debris flow event occurred (Autonomous Province of Bolzano, 2011b).

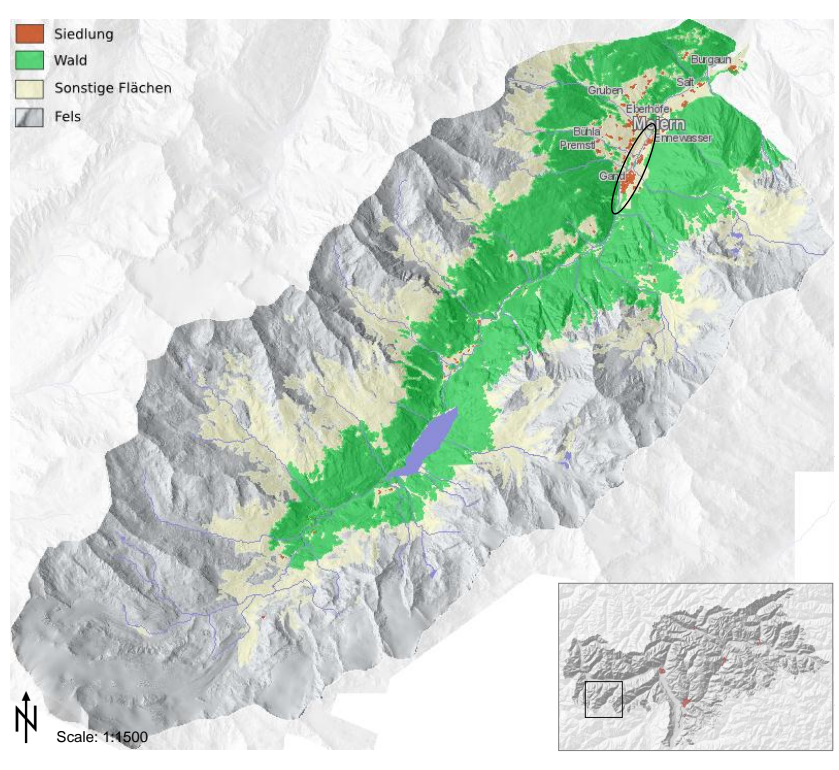

Fig. 1. Overview of the location of the research valley in the Autonomous Province of Bolzano/South Tyrol (2011a, overview map), the valley of Martell (indicated in the square) and its natural features itself (larger map, University of Innsbruck, 2008). The study area of the villages Gand and Ennewasser are encircled. Legend: red - settlement area, green - forest, light yellow - other areas such as alps, meadows and pasture areas, grey - rocks and high Alpine environment.

In the past, the settlement development was characterised by fluctuating numbers of population and since the late 19th century, Martell has shown a slight decline in population (Perkmann-Stricker, 1985). The main economic sector with the highest net production remains the agriculture, which has experienced a significant intensification since 1970 in form of orchards and the usage of sprinkling systems (Martell, 1998). The valley is embedded in the National Park Stilfersjoch and the focus lies on summer tourism. The number of tourist arrivals increased over time (2009 approx. 12000 per year), whereas the overnight stays (2009: 60000) stagnated on this level. Referring to the event and the years following 1987, no decline in touristic figures can be observed, although two guesthouses closed. (WIFO, 2010)

Martell was, and still is, constantly threatened by hazards related to water (avalanches, debris flow, hyperconcentrated flows). During Holocene retreat, glaciers left behind debris and unconsolidated rocks. Since then, this loose material has been available to be transported downstream by debris flows causing widespread damage. For instance, numerous devastating debris flow events were reported in the late 19th century, as glacial lake outburst floods repeatedly destroyed parts of the settlement Gand (Perkmann-Stricker, 1985). In 1956, a hydro power plant with a reservoir dam was constructed, which mainly served as an electrical power source, but also 


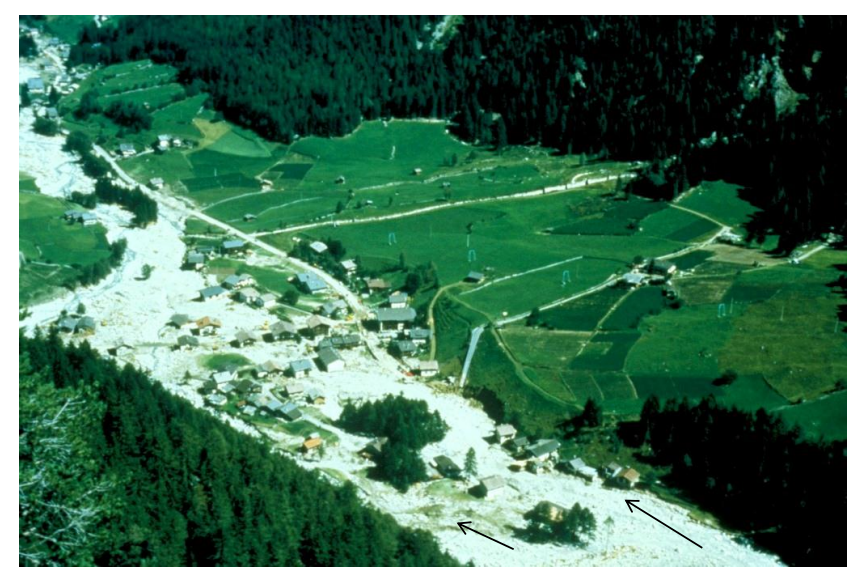

Fig. 2. Extent of the debris flow on 24 August 1987 (Municipality Martell, 1987). The arrows indicate the flow direction.

protected the village from abrupt flooding from the glacial and periglacial environment.

On 24 August 1987, following some days of continuous rainfall, the river Plima transported a significantly higher amount of water than usual. Debris flows were initiated in tributary streams along the valley; the general situation was tensed, awaiting a hazardous event. In the evening, the inhabitants were evacuated, as the water level was still rising. Approximately two hours after the evacuation, a tremendous debris flow went through the valley, leaving behind a scene of destruction. The main reason for the generation of the debris flow was an unfortunate concatenation of circumstances. The reservoir lake of the dam was filled to its maximum due to the rainfall. A power cut and the failure of the emergency generators led to a release of an excessive amount of water, as the water gates could not be closed automatically (Pfitscher, 1996). The outflow has been estimated to be threefold of the usual discharge ( 300 to $350 \mathrm{~m}^{3} \mathrm{~s}^{-1}$ ). The debris flow reached the village Gand around 21:00 LT, overflowed the river bed and found its way through the village (Fig. 2). Not only houses were destroyed, but also fields were flooded, the infrastructure was interrupted and an industrial zone in Vinschgau was devastated (Pfitscher, 1996). Fortunately, due to the early warning and evacuations there were no lives lost. The total damage summed up to 45 to 50 billion lire (approximately 23.2 to 25.8 million EUR). The damage for private households amounted to slightly less than $€ 8$ million. As far as the infrastructure, the construction yard, forestry, agriculture, tourism infrastructure and emergency response are concerned, damages of $€ 4$ million were recorded. Furthermore, $€ 5.6$ million needed to be spent to build up the regional road network, the telephone network and for torrent control measures. The indirect costs of the event were not assessed (Pfitscher, 1996).

\section{Methodology and uncertainties}

The present study focuses on the spatial and temporal comparison of the variation of the damage potential and the changes regarding the elements at risk (Akbas et al., 2009; Fuchs et al., 2004; Sterlacchini et al., 2007). A spatiotemporal approach attempts to answer the question: if it had happened at another point in time, would the event have had a higher impact? The emphasis is on detecting the changes of the spatial pattern of the built environment in the villages of Gand and Ennewasser using aerial images. The location and size of the buildings in relation to the debris intensities lead to a monetary estimation of the damages for each year. The constant factors are assumed to be the building structure, the hazard intensity, and as previously mentioned the vulnerability curve. For the account of the damage potential only the residential buildings were taken into consideration, whereas the calculation of the occupied built area, all building elements such as car ports or barns are included. Figure 3 presents the four main the steps of the applied method: aerial photos acting as basis information (A), an interpolated intensity map (B) based on the depth of the deposits in metres, the digitalisation of the elements at risk (C) and the resulting consequences (D).

\subsection{Intensity map}

The intensities affecting each building in 1987 were determined in a previous study of Papathoma-Köhle et al. (2012a). Photographic documentation directly after the event was used in order to acquire information regarding the debris flow intensity on each building and the respective damages. As no other physical or technical measurement instruments were available to record the intensity of the debris flow, the height of the debris was assessed at each element at risk by referring to the deposition itself, the splashes on the walls but also using the overall degree of damage. Having this information for each building in the villages of Gand and Ennewasser, it was possible to create an intensity map for the area throughout interpolation. The interpolation follows the principle of spatial correlation and common characteristics of objects that are closer together than farther apart. Using existing digital points for each building, an expansion map was created. A semi-variogram shows the dependency of the points to each other indicating the differences of two points being closer are lower than those being farther away. This means that buildings being close to each other experienced most likely the same or similar debris intensity. This step helped to ascertain the assumption of the hypothetic occurrence of the event from 1987 for any other time steps (1954, 1985, 1992, 1999 and 2006), given by the same intensity. Therefore, the intensity map is illustrating the distribution similar to the debris flow intensity of 1987 (Fig. 3, point A). The boundaries of the intensity deposit are given naturally, as the spread is limited by the slope degrees and valley bottom. The intensity 


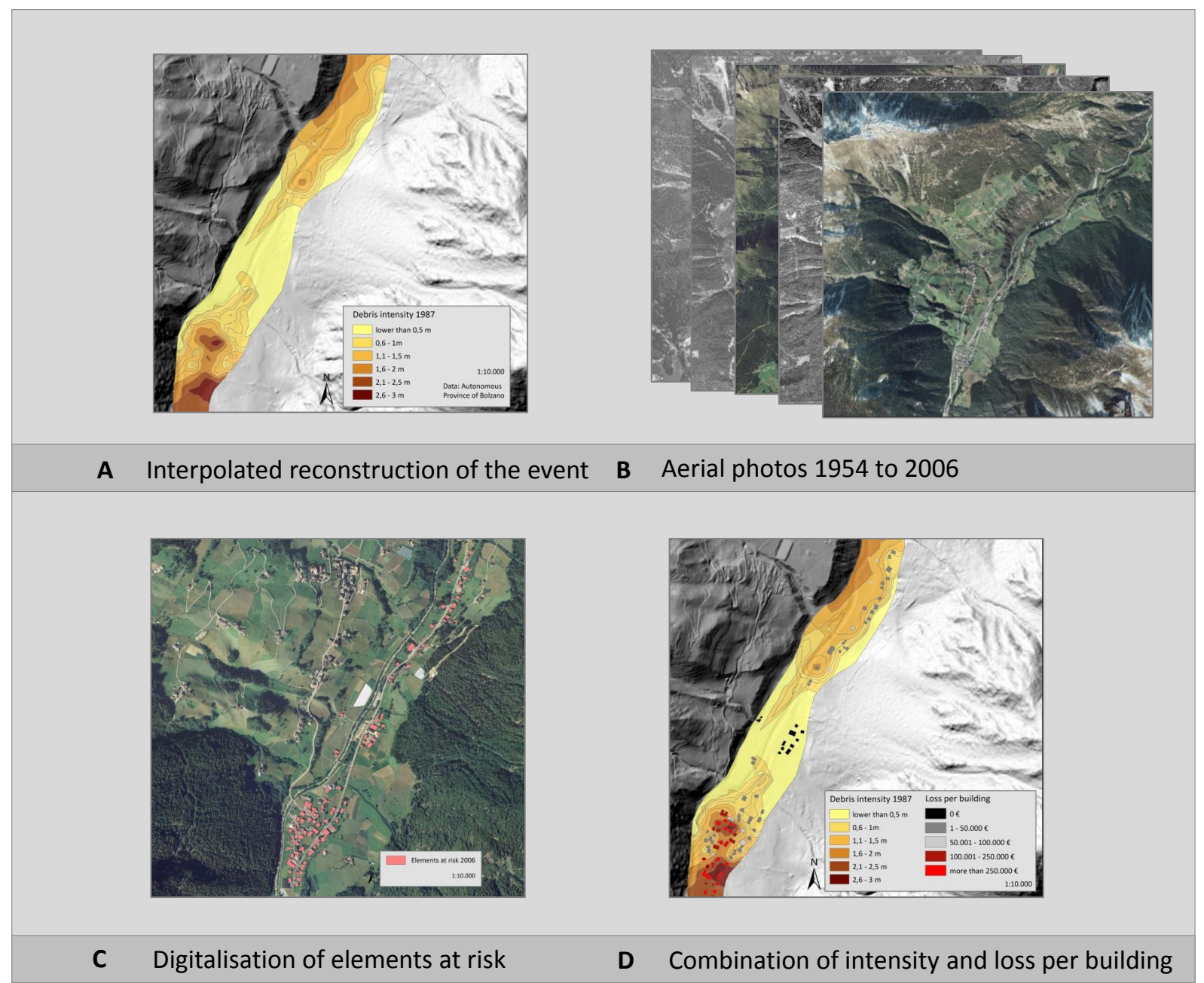

Fig. 3. Framework of the methodology: (A) The interpolated intensity map is based on the debris flow depths measured for individual buildings. (B) Aerial images serve as digitalisation base to (C) detect the elements at risk for different points in time. (D) By using the vulnerability curve and the information regarding the intensity the degree of loss for each year of research can be calculated.

map can then be overlaid with aerial photos of past (1954, $1985)$ and more recent years $(1992,1999,2006)$ in order to display the spatial pattern of the elements at risk within the intensity classes in different years.

\subsection{Data and mapping of the elements at risk}

The data used consisted primarily of aerial photos and served as the basis for digitalising the buildings (Fig. 3, point B). Additionally, historical images were used for validation as they indicate the settlement structure at different points in time. The first aerial photo originates from 1954 and - due to the rather poor quality - historical pictures were consulted to allocate the buildings properly. These pictures were included in the historical book from the municipality (PerkmannStricker, 1985) and were also collected during a field work. The second aerial photo is from 1985, two years before the event occurrence and shows a comparable spatial pattern of the built environment before the devastating event. The aerial photo from 1992 gives an excellent overview of the direct changes after the event. The last two research years (1999 and 2006) function as a more recent overview of the changes in the spatial pattern of the built environment and specifically show the increase in living space.

These aerial photographs are each independent recordings and for this reason their recording height, time and method varies (Table 1). The comparability is given by georeferencing, as they lie directly above each other and were rectified for further use.

\subsection{Digitalisation}

The buildings were manually digitised by focusing on their outer building boundaries (Fig. 3, point C). Using GISsoftware, the determined data can be easily visualised and further analysis can be carried out. The most recent available 
Table 1. Overview of the aerial images and their information (Autonomous Province of Bolzano, 2011c; University of Innsbruck, 2008).

\begin{tabular}{|c|c|c|c|}
\hline Date & Comment & Relevance for research objectives & Colour/black and white \\
\hline 1954 & $\begin{array}{l}\text { Prints in } 50 \mathrm{~cm} \times 50 \mathrm{~cm} \text {, rather poor quality, } \\
\text { distortions after scanning, not directed north- } \\
\text { wards, shadows }\end{array}$ & $\begin{array}{l}\text { Information regarding the settlement expansion } \\
\text { until the mid } 1950 \mathrm{~s}\end{array}$ & black and white \\
\hline 1985 & $\begin{array}{l}\text { Cross-country tread generated through manual } \\
\text { stereo appraisal }\end{array}$ & $\begin{array}{l}\text { Ideal for the assessment of the inventory of } \\
\text { buildings and their location before the event }\end{array}$ & black and white \\
\hline 1992 & Not digitally available & $\begin{array}{l}\text { Five years after the event }- \text { what has changed } \\
\text { and how? Were the flooded areas next to river } \\
\text { Plima resettled? }\end{array}$ & black and white \\
\hline 1999 & $\begin{array}{l}\text { Summer/Autumn 1999, Scale } 1: 10000 \text {, not } \\
\text { completely digital yet, resolution min. } 1 \mathrm{~m} \text {, } \\
\text { picture format } 23 \mathrm{~cm} \times 23 \mathrm{~cm}^{2} \text {, focal length } f \\
150 \mathrm{~mm}\end{array}$ & $6 \mathrm{yr}$ after the last aerial image & colour \\
\hline 2006 & $\begin{array}{l}\text { Most recent aerial image of the flight from } \\
\text { summer } 2006 \text {, scale } 1: 10000 \text {, entirely digital } \\
\text { available, CCD camera, not overlapping } \\
\text { recordings but scanning fields, resolution min. } \\
0.5 \mathrm{~m} \text {, picture format } 23 \mathrm{~cm} \times 23 \mathrm{~cm}^{2} \text {, focal } \\
\text { length } f 150 \mathrm{~mm}\end{array}$ & $\begin{array}{l}6 \mathrm{yr} \text { after the last aerial image, roughly the same } \\
\text { settlement extension as during the validation in } \\
2011\end{array}$ & colour \\
\hline
\end{tabular}

land register was applied to allocate street numbers. Moreover, the digitalisation scale was set to $1: 2000$ in order to ensure both a general image of the settlement without neglecting structural building features and an equal data and digitalisation quality. As the focus was set on physical vulnerability, all kinds of houses, such as residential and commercial or agricultural buildings, were mapped. However, gardens, forecourts and other surrounding objects were not included. Despite its importance and the fact of being heavily damaged by the event, the infrastructural vulnerability (street network, power lines, pipelines, etc.) was not considered in this study.

Calculating the potential loss of the investigated years, only residential buildings were considered, as they were the only ones included in the vulnerability curve. Using the intensity map, the referring deposition heights can be allocated to each element at risk.

\subsection{Vulnerability curve}

Based on event documentation, the heights of the debris flow deposits were estimated and the monetary damage per building was calculated. Papathoma-Köhle et al. (2012a) carried out a building-precise assessment of the debris flow intensities and the monetary loss of most of the affected buildings of the 1987 event. Overall, 69 buildings have been damaged or completely destroyed (Pfitscher, 1996), however, only 53 of these buildings were used for the development of the vulnerability curve (Fig. 4) as only for this amount of buildings adequate photographic documentation was available. In more detail, photos from the damage documentation and

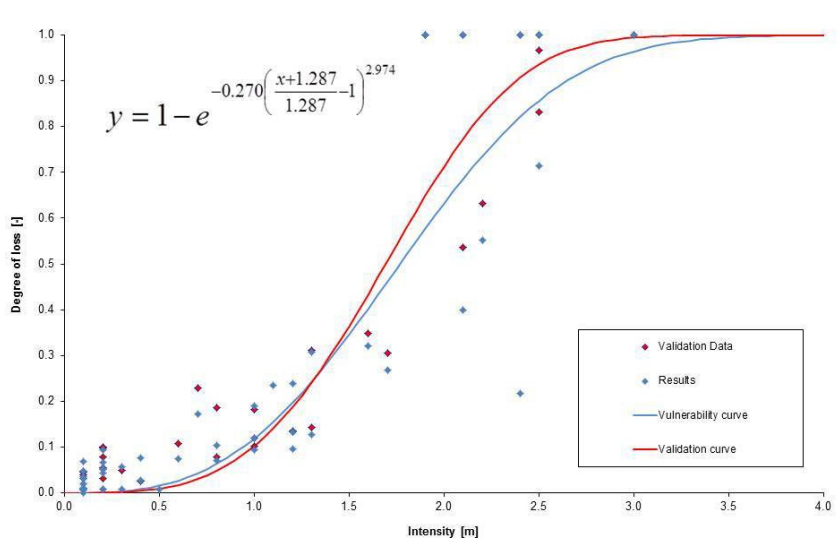

Fig. 4. Vulnerability curve (blue) and validation curve (red) developed using the buildings that were affected during the 1987 event in Ennewasser and Gand. The curves express the relationship between the degree of loss (0-1) and the intensity of the debris flow expressed as debris height (m) (Papathoma-Köhle et al., 2012).

additionally aerial photos were used to locate the buildings. By using photographic documentation the extent of damage was translated in monetary loss based on standard prices for renovation works. The degree of loss for each building has then been assessed by considering also the building value based on real compensation data and the size of the building (Papathoma-Köhle et al., 2012a).

The vulnerability curve evidently but clearly shows that the higher the intensity of the process the greater the damage to an element at risk. Papathoma-Köhle et al. (2012a) developed also a validation curve (red curve) (Fig. 4) using the 


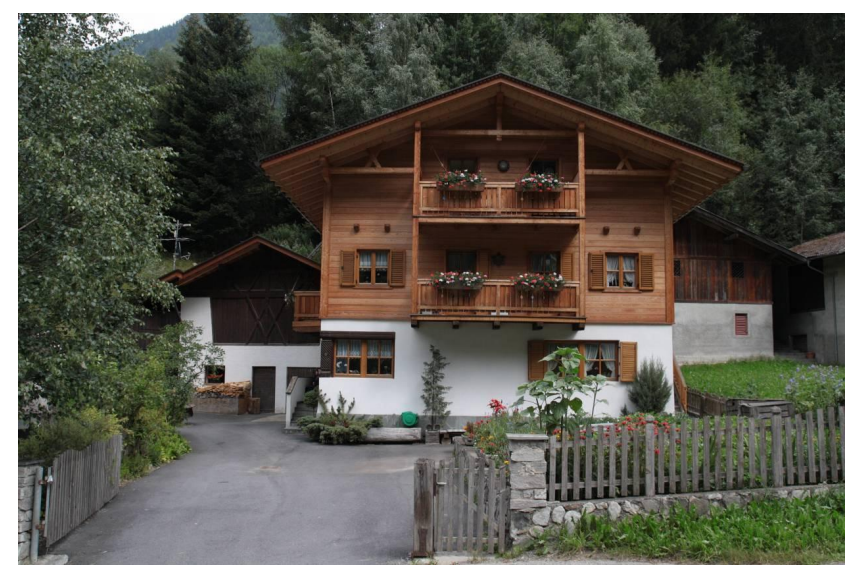

Fig. 5. Traditional residential building in Gand, number 27 (Photo: B. Schwendtner, 2011)

real compensation data from the specific event in 1987 for the calculation of the degree of loss. The visual comparison of the two curves demonstrated the reliability of the developed vulnerability curve.

In the present study, the specific vulnerability curve serves as the basis for assessing the monetary loss. As the intensities for each building are known for each point in time, the degree of loss can be ascertained based on the vulnerability curve (blue curve in Fig. 4). The respective degree of loss indicates the percentage of overall loss for a building (e.g. an element at risk with a degree of loss of 0.5 in 1987 had restoration costs of $50 \%$ of its overall building value).

\subsection{Uncertainties}

Inevitably, the application of the methodology had to be partially based on assumptions (e.g. the building structure remains the same throughout the time) which eventually led to a number of uncertainties. Firstly, there are uncertainties due to the poor quality of some of the aerial photos, as shadows and resolution vary greatly. Secondly, the buildings were digitised in an aerial perspective, which may be different to the real floor area of the building. Thus, the overall area may increase from the roof, which protrudes over the building by at least one metre. Moreover, large car ports or other buildings cannot clearly be distinguished from residential buildings. Therefore, during an intense field survey in 2011 , the actual building structure, likely being the one from 2006, was recorded. The building types, functions and features were recorded; the collocation of the buildings to each other was clarified and inaccuracies due to the primary data (aerial images) were eliminated. Furthermore, historical pictures functioned as validation for the years before the event. Consequently, a variance coefficient of $36 \mathrm{~m}^{2}$ was calculated to allow a range of square metres in the analysis. The variance coefficient has been derived by calculating the average size for each building and therefore the mean for all selected

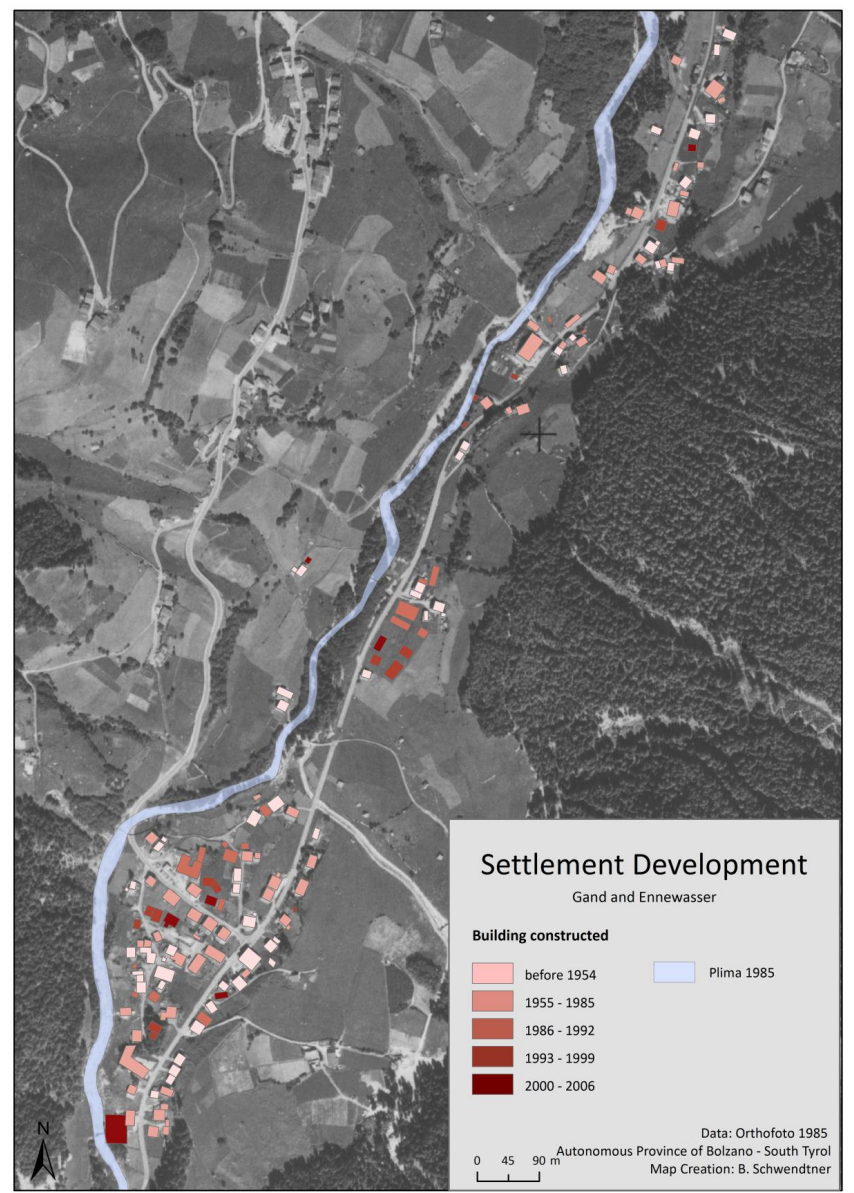

Fig. 6. Settlement development in Gand and Ennewasser from before 1954 until 2006.

points in time. For the loss estimation, a minimum, maximum and average value has been calculated. Further assumptions needed to be made regarding the number of floors. During the field visit, a detailed documentation has made that can be used for the research years after the event (1992, 1999 and 2006). For 1985, the same number of storeys was used as that from the event documentation and for 1954 historical photos were the source of information.

\subsection{Loss estimation and values of elements at risk}

As the debris flow deposit is known for every individual building due to the intensity map (Fig. 7), the loss estimation can be carried out. The calculation of the monetary damage is related to the building properties (height, ground surface) and the intensity class they are located in. The estimation of the value of each building is based on a standard compensation value per square metre and the size and height of the building (number of floors). The calculation of the degree of loss for each building was done by using the vulnerability curve in Fig. 4 and the information on the intensity of the process. 

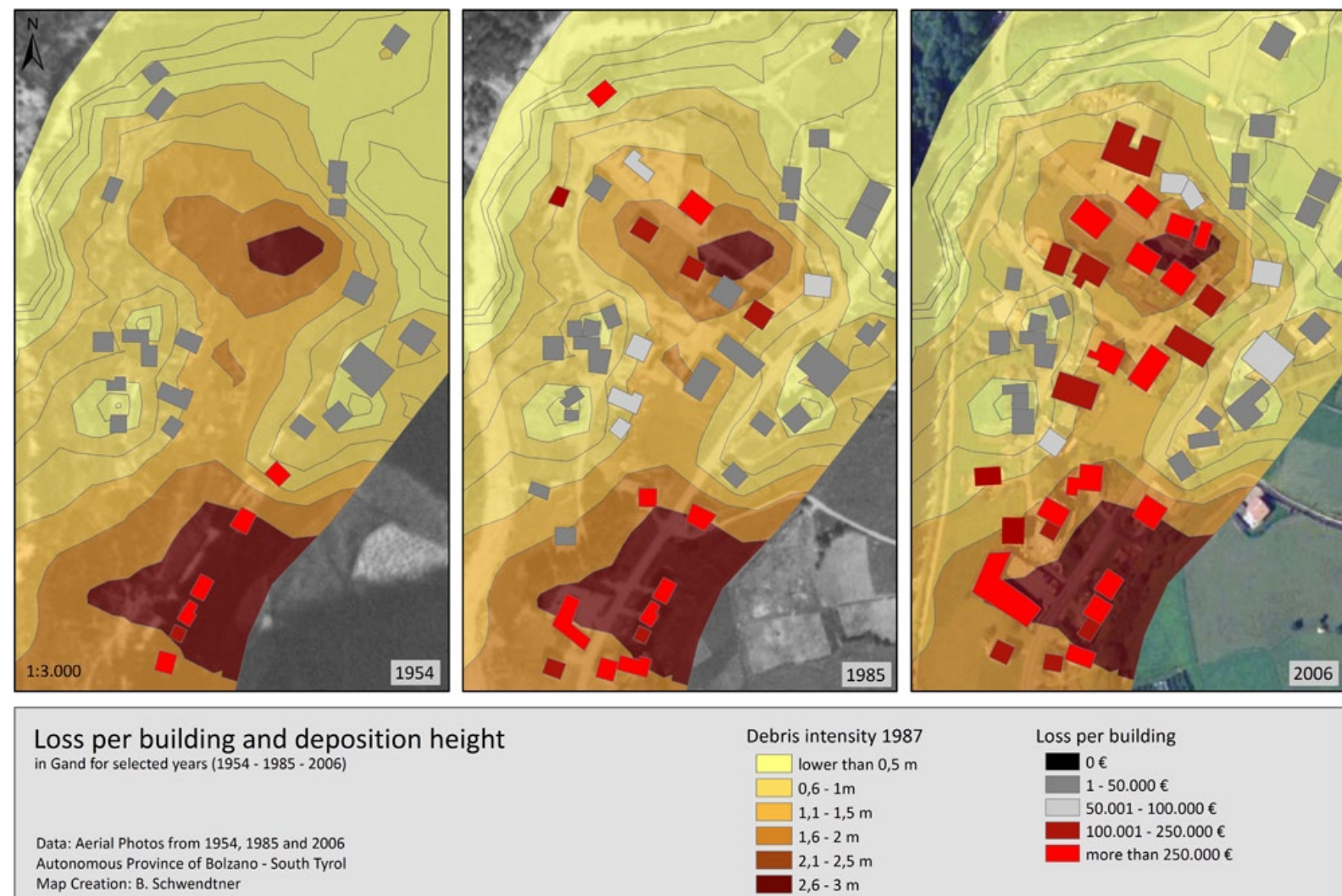

Debris intensity 1987

lower than $0,5 \mathrm{~m}$

$\square, 6=1 \mathrm{~m}$

$\square, 1-1,5 \mathrm{~m}$
$\square$

$1,6-2 \mathrm{~m}$

$2,1-2,5 \mathrm{~m}$

$2,6 \cdot 3 \mathrm{~m}$

Fig. 7. Visualisation of the damage potential and the deposition height of the 1987 event.

The following parameters were taken into consideration:

- area in square metres;

- number of floors;

- attic (distinction between attic used as living space or not);

- car port or other additional buildings;

- cellar.

The prices for living area, cellar and attic were taken from Papathoma-Köhle (2012a) and were based on data from Keiler (2004), Keiler et al. (2006) and the Autonomous Province of Bolzano (2010). Using this information, the overall value of each building can be calculated. For a restoration of the building to its original state, the working hours and additional repair work on the electricity, painting, etc., were taken into account (Kaswalder, 2009). The adjustment regarding the inflation has been already made in the primary data.

In order to illustrate the loss calculation process, an example is given. The residential building with the number 27 is located on the southern end of Gand (Fig. 5). The classic Alpine style house had in 2006 two floors and an attic, which is used as living space. Two additional buildings on both sides of the house were once used as stables or barns. The digitised living space is $268.71 \mathrm{~m}^{2}$. The specification of the ranging value allows an approximation of the real value of $269 \pm 36 \mathrm{~m}^{2}$ ( $\rightarrow 305$ and $233 \mathrm{~m}^{2}$, respectively). First, the overall value of the house is determined, by calculating the minimum (Eq. 1) and the maximum value (Eq. 2).

$$
\begin{aligned}
V_{\min } & =(A \times F \times p)+\left(a_{i} \times p_{i} \times \frac{A}{2}\right)+\left(a_{j} \times p \times \frac{A}{2}\right) \\
& +\left(n_{\mathrm{b}} \times A \times p\right) \\
V_{\max } & =V_{\min }+\left(n_{\mathrm{c}} \times p_{\mathrm{c}} \times A\right),
\end{aligned}
$$

where $A$ is the area in square metre, $F$ the number of floors, $p$ the price per square metre in $€, a_{i}$ attic not used as living space, $a_{j}$ attic used as living space, $p_{i}$ the price of the attic not used as living space in $€, n_{\mathrm{b}}$ the number of additional buildings, $p_{\mathrm{b}}$ the price of additional buildings per square metre in $€, n_{\mathrm{c}}$ the number of cellars, $p_{\mathrm{c}}$ the price of a cellar per square metre in $€$.

The referring values are inserted into the above described equations and the minimum and maximum values are calculated: 


$$
\begin{aligned}
V_{\min } & =(268.71 \times 2 \times 1153)+\left(0 \times 294.03 \times \frac{268.71}{2}\right) \\
& +\left(1 \times 1153 \times \frac{268.71}{2}\right)+(1 \times 149 \times 575.91) \\
& =860367 \\
V_{\max } & =860367+(1 \times 575.91 \times 268.71)=1015230 .
\end{aligned}
$$

In total, this calculation was carried out three times: using the derived surface of the digitalisation and with the variance coefficients of $+36 \mathrm{~m}^{2}$ and $-36 \mathrm{~m}^{2}$. Thus, a total of three values for the building have been obtained (minimum, maximum and average value). For further use of this data, the average value will be applied, which amounts to the previously discussed example of $€ 937743$.

Once the overall value of a building has been determined, the damage was calculated based on the event of 1987. For this purpose, the data of the intensity map is necessary because it provides information on the deposit height in a certain area. Using the existing vulnerability curve, the expected monetary loss per building was derived based on the percentage of the degree of loss. The damage per building was again calculated using the ranging values. For example, for the residential building in Gand 27, the intensity was $1.81 \mathrm{~m}$ in 1987 , which resulted in an overall loss of $52 \%$. Consequently, the potential damage of this house in 2006 would have been $€ 487626$ with a variance of \pm 59437 EUR. By repeating the above presented process for each building in the affected area, the overall loss of the event in each year of research was calculated. Furthermore, the losses were spatially visualised, as seen in Fig. 3d.

\section{Results}

The results show clearly that the research area has undergone various changes in the past decades. These changes were partially due to the hazardous event but also due to socio-economic changes (better economic situation resulting in smaller household sizes and less multi-generational houses, bigger houses, higher employment numbers in tertiary sector) which may have a significant influence to losses regarding natural hazards.

\subsection{Settlement development}

An overview of the housing development and the development period of the buildings is given in Fig. 6 (total number of buildings for each research year in Table 2). The illustration is based on the aerial photo of 1985 (two years before the event) showing the original river regime and some buildings, which were destroyed in 1987 and relocated thereafter. Until 1954, houses were mainly built along the main road. The next generation attached newly constructed homes to the existing older ones. As a result, the settlements in both districts Gand
Table 2. Number of buildings significantly affected (deposit height $>0.5 \mathrm{~m})$, less affected $(<0.1$ or $<0.5 \mathrm{~m})$ and the total number of residential buildings from 1954 to 2006 (1987 for comparison,

\begin{tabular}{|c|c|c|c|c|}
\hline \multirow[t]{2}{*}{ Date } & \multirow{2}{*}{$\begin{array}{r}\text { Significantly } \\
\text { affected } \\
>0.5 \mathrm{~m}\end{array}$} & \multicolumn{2}{|c|}{$\begin{array}{c}\text { Less } \\
\text { affected }\end{array}$} & \multirow[t]{2}{*}{$\begin{array}{r}\text { Total } \\
\text { number }\end{array}$} \\
\hline & & $<0.5 \mathrm{~m}$ & $<0.1 \mathrm{~m}$ & \\
\hline 1954 & 28 & 9 & 3 & 40 \\
\hline 1985 & 34 & 31 & 9 & 74 \\
\hline 1992 & 39 & 27 & 13 & 79 \\
\hline 1999 & 47 & 28 & 14 & 89 \\
\hline 2006 & 49 & 28 & 15 & 92 \\
\hline 1987 & 27 & 12 & 14 & 53 \\
\hline
\end{tabular}
Papathoma-Köhle et al., 2012). Note: The number of houses in 1987 is based on the data from the event documentation, where only slightly or significantly damaged buildings were included.

and Ennewasser have consolidated more and more over time. Especially between 1954 and 1985, an intense construction period can be observed, which is clearly visible in the village of Ennewasser.

After the event, two houses and four farm buildings were not rebuilt in the same place. In addition, the riverbed of Plima was regulated. Some of the former building plots were redesignated and kept unobstructed from settlement development. During the upcoming period between 1985 and 1992 five new buildings were constructed but also building extensions were created. The commercial and artisan area between Gand and Ennewasser also began to emerge during that time. Until 1999, three new houses were built around this area, and another seven in Ennewasser and Gand. After the turn of the millennium, three new houses were constructed but, compared to the previous periods, the growth was limited. It can be clearly seen that there was a tendency to consolidate the settlements rather than building houses within a distance from each other.

The area occupied by buildings and their sizes vary greatly and particularly larger complexes of trade areas distort the picture. Over time, there is an obvious increase in the building footprints both in mean and median. The pre-event period is dominated by rather small houses in size $\left(<100 \mathrm{~m}^{2}\right)$ and fewer stories. The post-event phase showed a tendency towards bigger houses $\left(>100 \mathrm{~m}^{2}\right)$ or extensions of an existing building. Furthermore, some extensively larger buildings such as a construction yard or a carpenter's shop, were constructed. Residential buildings with a floor area of less than $100 \mathrm{~m}^{2}$ have a rather low percentage in all research years. In 1954 and 1985, a balanced distribution ratio of buildings with an area of at least $100 \mathrm{~m}^{2}$ can be identified. In the $31 \mathrm{yr}$ between the first and second aerial photo, the built-up area has increased by $114 \%$, from 8705 to $18612 \mathrm{~m}^{2}$. In the following years, the building footprints moved towards bigger sizes of over $250 \mathrm{~m}^{2}$. On the contrary, in 1954 , only traditional 
guest houses were found in this size range. In general, buildings between 100 and $250 \mathrm{~m}^{2}$ represent a percentage of approximately $17 \%$, which has not changed in the time series. In subsequent periods of seven years (1992, 1999 and 2006), the built-up area first increased by $34 \%$ (from 18612 to $24876 \mathrm{~m}^{2}$ ), then by $14 \%$ (to $28295 \mathrm{~m}^{2}$ ), and by $7 \%$ (to $30311 \mathrm{~m}^{2}$ ). Thus, the time in between the study years was associated with an increase in the area occupied by buildings, which started with a considerable expansion and was followed by a lesser increase. Overall, the built-up area has increased by $248 \%$ between 1954 and 2006 (from 8705 to $30311 \mathrm{~m}^{2}$ ).

\subsection{Deposition heights and spatial distribution of elements at risk}

The spatial distribution of debris deposition for the 1987 event shows that Gand experienced generally higher deposits than Ennewasser, this is why Gand suffered the most severe damage and higher costs (Fig. 7, years shown: 1954, 1985 and 2006). Especially affected were the buildings at the southern end of Gand as the river Plima sought its way from the stream bed. The deposition heights reached up to $3 \mathrm{~m}$ in this area. In Fig. 7, a broad band of intensities of around $2 \mathrm{~m}$, which traces the transfer area of the debris flow, is clearly visible. In Ennewasser, deposition heights were not as high and a total destruction (degree of loss $=1$ ) has not been reported for the event of 1987. Obviously, the river found its way back to the main river course. The difference between Gand and Ennewasser can also be reflected in the difference in the average intensity in Gand $(1.2 \mathrm{~m})$ and Ennewasser $(<0.5 \mathrm{~m})$.

The temporal analysis regarding the development of the research area shows a clear trend towards constructing more buildings in areas with higher deposition intensity. This would be equal to a vulnerability of about 0.6 , based on the ratio between the deposition height and the degree of loss. Additionally, buildings can be considered potentially significantly affected by debris flows, when the deposition height is higher than $0.5 \mathrm{~m}$ as water and debris can intrude the building (Table 2). The term "less affected" ( 0.1 to $0.5 \mathrm{~m})$ indicates that the building will be damaged mainly on the outside or due to water and material entering the basement. Throughout the years, more than $50 \%$ of the buildings can be found in areas where they would have been significantly affected. In 1954, 28 buildings would be significantly affected; only three buildings would be largely unaffected. The following years of investigation show a change of the distribution. In 1985 and 1992 more than $50 \%$ of the elements at risk are located in areas where the intensity would be less than half a metre. This means that in the last $30 \mathrm{yr}$ a potential occurrence of the same event would have caused half of the existing buildings to be affected by intensities up to $0.5 \mathrm{~m}$. Nevertheless, a significant number of buildings are not affected and their percentage rose from $8 \%$ in 1954 up to $16 \%$ in 2006.

\subsection{The temporal evolution of the loss}

The results show a significant increase of the loss values over the years. More importantly, the results are in line with the amount of loss in 1987, as the loss increases in conjunction with the settlement development.

Detailed descriptions of the total potential damage and building values were calculated for each year. Overall, the building values between 1954 and 2006 have increased by $234 \%$, which corresponds to a tripling in value and is in accordance with the growth of constructed area. From 1954 to 1985 , the summed building values have doubled (from $€ 21.5 \pm 4$ million to $€ 43.7 \pm 7.7$ million). Thereafter, the increase has not been as strong as before, which is due to the shorter time intervals and a decline in construction activities. Nonetheless, between 1985 and 1992 there was still a large increase of $34 \%$, from 1992 to $199917 \%$ and until 2006 the building values changed by $5 \%$ with regard to 1999 . The average values are obtained by dividing the number of buildings included in the analysis, and the total for each year study year. Until 1985, the value remained at $€ 600000$ per home and increased until 1992 by $26 \%$ to almost $€ 750000$. The changes thereafter are marginal, as the building expansion only sparsely increased.

The degree of loss gives a better impression of the possible consequences on a monetary basis (Table 3 ). In 1954 , the damage would be less than $€ 2.4 \pm 0.6$ million. The total damage, $31 \mathrm{yr}$ later, would have been 2.6-fold, namely $€ 6.2 \pm 1.2$ million. As new buildings were constructed in zones, where the intensity in 1987 was up to three metres, the potential degree of loss in 1992 sums up to $€ 10.5 \pm 1.35$ million. Until 1999 , a further increase to $€ 13.2 \pm 1.7$ million was calculated. At the end of the time series in 2006, a total loss for residential buildings of $€ 13.9 \pm 1.8$ million could be expected. Between 1954 and 2006, the amount would have increased by 5.8 times. The average loss value per building would increase by $152 \%$. Thus, in 1954, the average loss per building can be set to $€ 59852 \pm 15000$. In 1985, the average loss per household is $€ 84110 \pm 16146$, in $1992 € 133218 \pm 17,138$ and in 2006 $€ 151043 \pm 19376$. The resulting values vary from more than $€ 2.4$ million in 1954 to $€ 13.9$ million in 2006, implying a potential six fold increase.

Generally, not all buildings are affected or damaged to the same extent, as the loss is dependent on the building age, quality and most importantly, the location and severity of the event. It needs to be stressed that the degree of loss per building is calculated for the entire house, thus is an average. Indeed only some parts will be affected, while others, e.g. on the averted side of the impact, suffer less damage. Median values give better statements regarding the loss per year for the study area (Table 3), as for 1954 half of the buildings would have recorded a loss of up to $€ 11239$, the other half would have to compensate more than this amount. In 1985, the distribution changed significantly as the median 
Table 3. Building values and the resulting potential loss in Euro including variance coefficient and mean value between 1954 and 2006.

\begin{tabular}{rrrrrr}
\hline Date & Value & \pm & Loss & \pm & Median \\
\hline 1954 & 21545702 & 4092873 & 2394082 & 603719 & 11239 \\
1985 & 43752145 & 7690671 & 6224105 & 1194821 & 5850 \\
1992 & 58799349 & 8299000 & 10524226 & 1353878 & 10727 \\
1999 & 68827853 & 9580196 & 13163381 & 1721678 & 19507 \\
2006 & 72062354 & 9866506 & 13895925 & 1782553 & 18362 \\
1987 & 16141108 & 1534512 & 7979257 & - & 19868 \\
\hline
\end{tabular}

is $€ 5850$. In 1992, almost the level of 1954 ( $€ 10727)$ is reached and in 1999 the median rises up to slightly under $€ 20000$. In 2006, the median declines again to $€ 18362$.

Furthermore, there are clear differences between Gand and Ennewasser. Especially the southern part of Gand is affected, as the debris flow hit those buildings first. In 1954, the damage would have accounted $€ 2.2 \pm 0.57$ million in Gand, while Ennewasser only would have compensated one-sixteenth of the total spend in Gand. A similar result would have been obtained for 1985, where the total damages in Gand would be $€ 6 \pm 1.16$ million, but only $€ 224753 \pm 36867$ in Ennewasser. In the following years, the degree of loss in Gand is about nine times higher than in Ennewasser. It is especially noteworthy that the overall damage in Ennewasser between 1954 and 1985 has not even doubled. Until the next study in 1992, however, a sharp increase of over $€ 1$ million of potential damage can be identified, which is due to the settlement expansion in this period. Moreover, the deposition intensity in 1987 was significantly lower than in Gand, which is why many buildings remained intact and would be less affected by a similar event. Also, the average damage value is much higher in Gand which sums up to $€ 233705$ compared to only $€ 42000$ in 2006 for Ennewasser. It can be concluded that the lower deposition intensities in Ennewasser would clearly result in much lower damage values.

A comparison of the spatial deposition intensities with the overall damage value is shown in Fig. 7. There is an obvious coherence which concludes that the higher the intensities are, the higher the loss will be. Table 4 shows the average loss per building for pre-defined intensity classes. Elements at risks, which were affected by a smaller amount of debris, suffer significantly less damage. As long as buildings are in areas, where the intensities were below $0.1 \mathrm{~m}$, the damage is significantly lower and tends towards zero. Relatively minor damages of less than $€ 50000$ are mainly found in Ennewasser. The average for the lowest intensity class between 0.1 and $0.5 \mathrm{~m}$ for all research years lies at $€ 3000$. The following intensity class $(0.6$ to $1 \mathrm{~m})$ indicates a clear increase of the degree of loss between $€ 50000$ to $€ 100000$, as the debris flow material can enter buildings. The greatest potential for damage is to be expected for the deposition heights from 2.1 to $2.5 \mathrm{~m}$, particularly since 1992 , as the average damage reaches a sum in excess of $€ 700000$. The following intensity classes (larger $2.5 \mathrm{~m}$ ) show by far a smaller amount of damage, which is due to the smaller amount of residential buildings in those classes and a higher probability of completely destroyed elements at risk. In 1954, five buildings would have been in the class $>2.5 \mathrm{~m}$, in the following research years there were only three. Furthermore, the potential loss also depends on the average size of the buildings, which is in 1954 relatively smaller compared to other research years.

\section{Discussion and conclusion}

The municipality of Martell is characterized by settlement expansion and increase in building size and value. By reconstructing the deposit heights and developing an intensity map of the event in 1987, the potential loss in different years was identified. The amount of damage increases over time, due to increased settlement development and the construction of new buildings in high intensity areas. The main settlement area is the village Gand, which is consequently the most densely settled part in Martell. The highest degrees of loss were determined in the central part of the village, which was due to the accumulation of debris flow material during the event in 1987. Moreover, significant differences between Gand and Ennewasser can be identified through time, as Gand would have been severely affected during all investigated years in comparison with Ennewasser. However, development trends clearly show that the risk potential in Ennewasser is significantly lower through time and there is a strong trend in increasing building development in Gand where the damages have been significantly higher.

The years after the event were characterized by rebuilding destroyed houses at similar locations and followed by a settlement spread. New houses were built in zones where debris flow intensity was higher and would cause equal or even higher damage values if the 1987 event would occur again. Nonetheless, the area right next to the river Plima has been kept clear for any built-up areas as a form of active risk management using spatial planning tools. Consequently, the potential damage is reduced in these areas.

The overall development of the municipality of Martell be reflected considering contains various aspects. The number 
Table 4. Resulting loss values in Euro in comparison with the deposit intensity in metres.

\begin{tabular}{lrrrrrr}
\hline Years & \multicolumn{6}{c}{ Deposition intensity and average loss in Euro } \\
\cline { 2 - 7 } & 0.1 to $0.5 \mathrm{~m}$ & 0.6 to $1 \mathrm{~m}$ & 1.1 to $1.5 \mathrm{~m}$ & 1.6 to $2 \mathrm{~m}$ & 2.1 to $2.5 \mathrm{~m}$ & 2.6 to $3 \mathrm{~m}$ \\
\hline 1954 & 724 & 18089 & - & 250857 & - & 347749 \\
1985 & 2766 & 29897 & 117842 & 222172 & 477885 & 315528 \\
1992 & 4191 & 35579 & 199870 & 396414 & 746046 & 469688 \\
1999 & 3755 & 36263 & 187905 & 425208 & 835063 & 550919 \\
2006 & 3561 & 43558 & 216775 & 470985 & 786284 & 449871 \\
\hline Average & $€ 2999$ & $€ 32677$ & $€ 180598$ & $€ 353127$ & $€ 711319$ & $€ 426751$ \\
\hline
\end{tabular}

of people employed in agriculture has fallen drastically, causing the majority working in the tertiary sector, mostly commuting to nearby villages in the Vinschgau. Nonetheless, only a few farms were abandoned and the primary sector is still the largest contributor to the economic value of the community. The municipality has enhanced its knowledge and capacities in various ways, which are expressed by concepts and strategies, such as an intensified agricultural use (orchards) or focussing on summer tourism. Notwithstanding that population decreased in the study area during the investigated period, the settlement development has indeed increased, which means that some families have remained living in the valley. The amount of elements at risk increased in conjunction with an increment of the living area and a decline in the size of households. The settlement structure has undergone a considerable change from being fairly compressed to a more structured arrangement of houses. The results are in accordance with other studies using spatiotemporal approaches to assess loss estimations and changes in physical vulnerability (Fuchs et al., 2012a, b; Keiler et al., 2006; Quan Luna et al., 2011, etc.) and focusing on the development of Alpine villages (Bätzing, 2003).

The results of the study can also be seen in the context of global change and the modifications in the valley of Martell in the respective investigated time span of $52 \mathrm{yr}$. The analysis of the settlement expansion in a long run gives information about possible planning strategies and hazard zone mapping. The agricultural intensification plays an important role in the valley, where potential direct and indirect losses can be expected in case of a natural hazard. The results provide decision makers with an overview of how the settlement development and consequently the size of the consequences of a potentially hazardous event evolved throughout time. Moreover, decision makers are provided with a tool in order to assess the loss that may be expected in the area, should an event similar to the one of 1987 happen again. The representation of the possible consequences in space and time appear to be very valuable for the identification of endangered areas and areas that need more attention regarding building policies, protection measures, etc. Local authorities can make informed decisions regarding relocation or reinforcement of buildings and location as well as type and size of structural mitigation measures. The results of the present study can be used for cost benefit analysis for protection measures since information regarding the costs of the "do nothing" option can be compared with the costs of the option of adopting structural measures. In this way, the design of adequate riskreduction strategies will be enabled and politicians can be easily convinced to fund these strategies. Moreover, the information can also be used for emergency planning since prioritisation of efforts can be based on the intensity map, on the spatial pattern of the built environment and the density of the population based on the distribution and use of the buildings. Future land use plans can be acquired by the municipality and can be integrated in the study. In this case the loss of a similar event in the future (e.g. in 20 or $50 \mathrm{yr}$ ) can also be estimated. Moreover, more elements at risks can be also considered such as agricultural areas or touristic facilities that also suffer considerable loss when impacted by debris flows.

In the present study, only direct costs (building rehabilitation) and renovation were considered. In future studies more direct costs (e.g. buildings content) or indirect costs (compensation for immediate temporary housing for evacuees) could also be included. Last but not least, the hazard itself can be further investigated and remodelled. However, the 1987 event was partly a man-made event. Although the hydroelectric plant is still in use, the possibility of a similar event happening again is low. Nevertheless, the area has suffered regularly from debris flow events in the past which are also expected to be more frequent due to climate change (IPCC, 2012). A thorough hazard assessment and mapping of debris flow in the area can provide a new basis for a similar study.

Acknowledgements. The authors would like to thank Andreas Zischg (Abenis) for the provision of the aerial images, the local authorities of Bolzano and the municipality of Martell for the provision of additional data. The research presented here was partly supported by the EU project MOVE (Methods for the Improvement of Vulnerability Assessment in Europe, www.move-fp7.eu, contract number 211590) and the "Back to Research" Grant provided by the Faculty of Earth Sciences, Geography and Astronomy of the University of Vienna. Furthermore, the authors kindly thank 
Byron Quan Luna for his insightful help, Margreth Keiler and two anonymous referees for their valuable inputs.

Edited by: L. Bouwer

Reviewed by: M. Keiler and two anonymous referees

\section{References}

Akbas, S. O., Blahut, J., and Sterlacchini, S.: Critical assessment of existing physical vulnerability estimation approaches for debris flows, in: Proceedings of landslide processes: from geomorphologic mapping to dynamic modeling, edited by: Malet, J. P., Remaitre, A., and Bogaard, T., Strasburg, 2009.

Autonomous Province of Bolzano: Schätzungsstudie zur Berechnung des Schadenspotentials bei Hochwasserereignissen durch die Rienz im Abschnitt Bruneck-St. Lorenzen, Department Wasserschutzbauten, Amt für Wildbach- und Lawinenverbauung Ost, Bozen, South Tyrol, 2009.

Autonomous Province of Bolzano: Richtpreisverzeichnis Hochbauarbeiten 2010. Abteilung Hochbau und technischer Dienst, Ressort Bauen, Bozen, South Tyrol, 2010.

Autonomous Province of Bolzano: Geobrowser, Abteilung Informationstechnik, available at: http://gis2.provinz.bz.it/geobrowser/ (last access: 16 July 2013), 2011a.

Autonomous Province of Bolzano: Climate Data 1921 to 2010, Hydrographical Department, South Tyrol, 2011b.

Autonomous Province of Bolzano: Aerial images, Department for Spatial Planning, South Tyorl, available at: http://www.provinz. bz.it/informatik/kartografie/landeskartografie-orthofoto.asp (last access: 16 July 2013), 2011c.

Bätzing, W.: Die Alpen - Geschichte und Zukunft einer europäischen Kulturlandschaft, Verlag C. H. Beck oHG, München 1991, München, 2003.

Bell, R., Greiving, S., Pohl, J., Röhrs, M., Glade, T., Thiebes, B., and Mayer, J.: Untersuchungsgebiete, in: Integrative Frühwarnsysteme für gravitative Massenbewegungen (ILEWS), edited by: Bell, R., Mayer, J., Pohl, J., Greiving, S., and Glade, T., Monitoring, Modellierung, Implementierung, Klartext Verlag, Essen, 2010.

Eidsvig, U. M. K.: Vulnerability and Risk Assessment for Geohazards, Vulnerability quantification for landslides and tsunamis, ICG Report 2006-2-14, NGI Report 20061032-14, 2009.

Fuchs, S., Bründl, M., and Stötter, J.: Development of avalanche risk between 1950 and 2000 in the Municipality of Davos, Switzerland, Nat. Hazards Earth Syst. Sci., 4, 263-275, doi:10.5194/nhess-4-263-2004, 2004.

Fuchs, S., Keiler, M., Zischg, A., and Bründl, M.: The long-term development of avalanche risk in settlements considering the temporal variability of damage potential, Nat. Hazards Earth Syst. Sci., 5, 893-901, doi:10.5194/nhess-5-893-2005, 2005.

Fuchs, S., Heiss, K., and Hübl, J.: Towards an empirical vulnerability function for use in debris flow risk assessment, Nat. Hazards Earth Syst. Sci., 7, 495-506, doi:10.5194/nhess-7-4952007, 2007.

Fuchs, S., Keiler, M., Sokratov, S., and Shnyparkov, A.: Spatiotemporal dynamics: the need for an innovative approach in mountain hazard risk management, Nat. Hazards, 1-25, doi:10.1007/s11069-012-0508-7, 2012a.
Fuchs, S., Ornetsmüller, C., and Totschnig, R.: Spatial scan statistics in vulnerability assessment - an application to mountain hazards, Nat. Hazards, 64, 2129-2151, 2012b.

Hufschmidt, G., Crozier, M., and Glade, T.: Evolution of natural risk: research framework and perspectives, Nat. Hazards Earth Syst. Sci., 5, 375-387, doi:10.5194/nhess-5-375-2005, 2005.

IPCC: Managing the Risks of Extreme Events and Disasters to Advance Climate Change Adaptation, in: A special report of Working Groups I and II of the Intergovernmental Panel on Climate Change, edited by: Field, C. B., Barros, V., Stocker, T. F., Qin, D., Dokken, D. J., Ebi, K. L., Mastrandrea, M. D., Mach, K. J., Plattner, G.-K., Allen, S. K., Tignor, M., and Midgley, P. M., Cambridge, UK and New York, NY, USA, Cambridge University Press, 2012.

Kaswalder, C.: Schätzungsstudie zur Berechnung des Schadenspotentials bei Hochwasserereignissen durch die Rienz im Abschnitt Bruneck - St. Lorenzen, Autonome Provinz Bozen - Südtirol, Bozen, South Tyrol, 2009.

Keiler, M.: Development of the damage potential resulting from avalanche risk in the period 1950-2000, case study Galtür, Nat. Hazards Earth Syst. Sci., 4, 249-256, doi:10.5194/nhess-4-2492004, 2004.

Keiler, M., Zischg, A., Fuchs, S., Hama, M., and Stötter, J.: Avalanche related damage potential - changes of persons and mobile values since the mid-twentieth century, case study Galtür, Nat. Hazards Earth Syst. Sci., 5, 49-58, doi:10.5194/nhess-5-492005, 2005.

Keiler, M., Sailer, R., Jörg, P., Weber, C., Fuchs, S., Zischg, A., and Sauermoser, S.: Avalanche risk assessment - a multi-temporal approach, results from Galtür, Austria, Nat. Hazards Earth Syst. Sci., 6, 637-651, doi:10.5194/nhess-6-637-2006, 2006.

Martell: Martelltal Wissenswertes, available at: http: //www.gemeinde.martell.bz.it/gemeindeamt/html/

MartelltalWissenswertes.pdf, last access: 16 July 2013.

Martell: Event Documentation, Municipality Martell, 1987.

Martell: Newsletter Martell, available at: http://www.gemeinde. martell.bz.it/gemeindeamt/download/219782890_1.pdf (last access: 16 July 2013), 1998.

Papathoma-Köhle, M., Kappes, M., Keiler, M., and Glade, T.: Physical vulnerability assessment for alpine hazards: State of the art and future needs, Nat. Hazards, 58, 645-680, 2011.

Papathoma-Köhle, M., Keiler, M., Totschnig, R., and Glade, T.: Improvement of vulnerability curves using data from extreme events: a debris flow event in South Tyrol, Nat. Hazards, 64, 2083-2105, 2012a.

Papathoma-Köhle, M., Totschnig, R., Keiler, M., and Glade, T.: A new vulnerability function for debris flow-The importance of physical vulnerability assessment in alpine areas, 12th Congress INTERPRAEVENT 2012-Grenoble/France, conference Proceedings, 1033-1043, 2012b.

Perkmann-Stricker, A.: Das Martelltal - eine Chronik, Gemeinde Martell, Martell, 1985.

Pfitscher, A.: Wasserkatastrophen im Martelltal - Der 24./25. August 1987, Municipality Martell, 1996.

Quan Luna, B., Blahut, J., van Westen, C. J., Sterlacchini, S., van Asch, T. W. J., and Akbas, S. O.: The application of numerical debris flow modelling for the generation of physical vulnerability curves, Nat. Hazards Earth Syst. Sci., 11, 2047-2060, doi:10.5194/nhess-11-2047-2011, 2011. 
Rickenmann, D.: Murgänge in den Alpen und Methoden zur Gefahrenbeurteilung, in: Mitteilungen des Lehrstuhls und Instituts für Wasserbau und Wasserwirtschaft, RheinischWestfälische Technische Hochschule Aachen, 124, 51-77, 2001. Sterlacchini, S., Frigerio, S., Giacomelli, P., and Brambilla, M.: Landslide risk analysis: a multi-disciplinary methodological approach, Nat. Hazards Earth Syst. Sci., 7, 657-675, doi:10.5194/nhess-7-657-2007, 2007.

UNDRO: Disaster prevention and mitigation - a compendium of current knowledge, Preparedness aspects, Vol. 11, New York, 1984.
University of Innsbruck: Kulturlandschaftswandel Südtirol Der Wandel seit 1950, available at: http://www.uibk.ac.at/ geographie/projects/kls/martell/ueberblick.html (last access: 16 July 2013), 2008.

WIFO Wirtschaftsforschungsinstitut: Südtirol: Anzahl der gastgewerblichen und nichtgastgewerblichen Beherbergungsbetriebe, Betten, Ankünfte und Nächtigungen. WIFO Wirtschaftsforschungsinstitut der Handelskammer Bozen, Bozen, South Tyrol, 2010. 